\title{
Energy efficiency in Indonesia's manufacturing industry: a perspective from Log Mean Divisia Index decomposition analysis
}

Dhani Setyawan ${ }^{1,2}$ (D)

\begin{abstract}
This research discusses energy intensity in Indonesia's manufacturing sector from 1980 to 2015. The manufacturing sector is the second-largest energy-consumer in Indonesia (after the transportation sector) and one of the largest contributors to Indonesia's output. Thus, it is important to know the energy usage performance of this sector. This study discusses the factors affecting changes in energy consumption in various subsectors of Indonesia's industry and investigates the energy intensity across manufacturing subsectors. This paper analyses the specific characteristics of energy intensity in the manufacturing sector in Indonesia from 1980 to 2015. This has not been investigated a great deal in the past, particularly when employing the Log Mean Divisia Index II method. The overall energy intensity of Indonesia's manufacturing sectors has seen a strong and continuous decline, with a reduction of $65 \%$ over the $35 \mathrm{yr}$, reinforced by some limited changes in industry structure towards lower intensity. Over the entire period, this reduction was dominated by increases in energy efficiency within industries, as indicated by a $62 \%$ fall in the within-industry intensive index. By contrast, the effect of moving to a less intensive industry structure was much less important (a $9 \%$ fall in the structural index). The greatest rise in energy efficiency within the industry happened before the financial crisis (from 1980 to 97). the shock of the financial crisis saw an unexpected reaction when value-added fell by $13 \%$ but energy use remained largely unchanged, implying a rise in energy intensity. From 2000 to 2015 the earlier trends resumed, but at a more subdued pace, where over this period aggregate intensity fell by $23 \%$.
\end{abstract}

Keywords: Energy efficiency, Manufacturing, Energy intensity, Indonesia

\section{Introduction}

Energy demand and greenhouse gas emissions in Indonesia have increased rapidly in recent years [1]. The energy consumption in the manufacturing sector accounts for around $40 \%$ of total final energy consumption in Indonesia in 2016, which is also the second-highest energy-consuming sector after the transportation sector. Based on International Energy Agency (IEA) [2], energy consumption

Correspondence: dhanisetyawan83@gmail.com

${ }^{1}$ Victoria Institute of Strategic Economic Studies, Victoria University,

Melbourne 14428, Australia

${ }^{2}$ Ministry of Finance of the Republic of Indonesia, Jakarta 10710, Indonesia growth in Indonesia has not coincided with a reduction of energy intensity, this is mainly due to efficiency improvements from new investment in the industrial sector and structural shifts in the economy.

The manufacturing sector is one of the most vital sectors in Indonesia as it contributes significantly to national energy consumption and output (Gross Domestic Product/GDP). According to the Indonesian Statistic Bureau (ISB), since the 1990s the manufacturing sector has become the largest contributor to Indonesia's energy consumption and national output. The manufacturing sector has accounted for around 27\% of Indonesia's

(c) The Author(s). 2020 Open Access This article is licensed under a Creative Commons Attribution 4.0 International License, which permits use, sharing, adaptation, distribution and reproduction in any medium or format, as long as you give

appropriate credit to the original author(s) and the source, provide a link to the Creative Commons licence, and indicate if changes were made. The images or other third party material in this article are included in the article's Creative Commons licence, unless indicated otherwise in a credit line to the material. If material is not included in the article's Creative Commons licence and your intended use is not permitted by statutory regulation or exceeds the permitted use, you will need to obtain permission directly from the copyright holder. To view a copy of this licence, visit http://creativecommons.org/licenses/by/4.0/. 
GDP in 2016 [3]. In the last $5 \mathrm{yr}$, the value-added from this sector has grown averagely at a rate of $5 \%$ per year Along with the manufacturing output growth, the energy consumption also rose in the previous $5 \mathrm{yr}$ from 3 to $4 \%$ growth annually. Interestingly, the rate of growth in energy consumption is slightly lower than the rate of growth in value-added. Based on this estimate, it can be said that the energy efficiency of the manufacturing sector has improved over time. Hence, looking at this trend, it is essential to examine and identify which sectors have the greatest potential to improve energy intensity in the manufacturing sector.

This study aims to examine the driving forces affecting changes in aggregate energy intensity in various sectors of Indonesia's manufacturing industry and investigate the energy intensity and value-added performance across manufacturing sectors. This study analyses the characteristics of energy intensity in the manufacturing sector in Indonesia from 1980 to 2015. This area has not had a great deal of research in the past of Indonesia's literature particularly by employing the Log Mean Divisia Index-II (LMDI-II) method. The analysis of industrial energy consumption has been conducted for several countries in the international context, but it is found insufficient in the Indonesian case. This study aims at filling this gap by focussing on identifying the factors affecting changes in energy intensity resulting from decomposition.

By conducting the decomposition method across Indonesia's manufacturing sector, this will provide further insight into the energy intensity performances. This study provides valuable evidence and information which adds to the knowledge/research into the study of energy use in Indonesia. The findings will help subsequent researchers and policymakers to understand what forces drive energy intensity, so this can inform policy aimed at reducing energy consumption in Indonesia in the manufacturing sector.

\section{Literature review}

Many studies have been conducted to investigate the relationship between energy consumption, economic growth and environmental aspects in Indonesia [4-6]. However, there are very few studies employing the decomposition method in Indonesia that measure the factors affecting energy intensity $[7,8]$ and environmental analysis [9]. Previous research generally focused on the manufacturing sector's energy consumption, while this study extends the investigation by adding subsectoral data to provide further insight into the energy system.

The first attempt to investigate the factors affecting energy consumption in Indonesian manufacturing was conducted by Sitompul [9] by using three-digit level data disaggregation (9 sectors and 30 subsectors) from 1980 to 2000, and applied decomposition analyses developed by Sun [10] to separate the energy intensity into technical effects and fuel mix effect. The result shows that the major contributor to the energy intensity changes in Indonesia is a technical effect.

Hartono et al. [7] decomposed the changes in energy intensity in the manufacturing sector into activity and efficiency effects from 2002 to 2006. In the analysis, they partitioned the industry into nine subsectors and divided the industry into two types: medium enterprises (firms that have less than 100 employees) and large enterprises (firms that have more than 100 employees). They found that the level of energy intensity in each industry level varies across subsectors and the changes in energy intensity in the national level are determined by large enterprises. He also found that the level of energy intensity is influenced by capital intensity, wages and capital share.

Vivadinar et al. [8] measured the factors affecting energy intensity and consumption in the manufacturing sector, focusing on high energy consumption industries: steel, pulp and paper, cement and glass, chemical and nonmetallic industries. They applied the decomposition method employing annual industry data from 2001 to 2007. They found that the changes in the energy demand and intensity were a result of the technology factor, whereas the role of production output was relatively small. However, the structural effect significantly affected the energy intensity in the glass and pulp industries.

Ramstetter and Narjoko [11] investigated whether multinational corporations were more energy-efficient than stateowned enterprises in Indonesian industries, focussing on medium to large manufacturers over the period 1996 to 2006. By using a translog production function model, they found that the relationship between energy intensities and ownership amongst Indonesia's manufacturing sectors was relatively weak. Another recent study by Setyawan [12] discovered that the aggregate energy intensity in the Association of South East Asian Nations countries was decreasing. By benchmarking the economy-wide energy intensity performances of Singapore, Malaysia, Vietnam, the Philippines, Thailand and Indonesia, he found that all these countries showed a shift in industry value added to more energyintensive industries.

\section{Material and methods}

This study employs the LMDI-II in multiplicative form, following the model developed by Ang [13, 14], to investigate Indonesia's manufacturing sector for the period from 1980 to 2015. The aggregated manufacturing energy intensity is defined by Eq. (1) below

$$
I=\frac{E}{Y}
$$

Where I denotes Energy Intensity (TJ/million Rupiah 
1980), E is manufacturing sector energy consumption (TJ) and $\mathrm{Y}$ represents manufacturing value-added at 1980 constant prices (in million Rupiah). In 1980 exchange rate, 1 USD equals to 626 Indonesian domestic rate Rupiah.

This study will refer to decomposition analysis described below, where Indonesia's energy intensity includes two factors: the intensity effect of each subsector in manufacturing $\left(D_{\text {int }}\right)$ and the structural effect of manufacturing $\left(\mathrm{D}_{\text {str }}\right)$. The decomposition method is computed as follows:

$$
\begin{aligned}
& D_{\text {tot }}=D_{\text {str }} \cdot D_{i n t}=\frac{I_{t}}{I_{0}} \\
& D_{s t r}=\exp \sum_{i}^{n}\left(\frac{L\left(w_{i, t}, w_{i, o}\right)}{\sum_{i}^{n} L\left(w_{i, t}, w_{i, o}\right)} \ln \left(\frac{S_{i, t}}{S_{i, 0}}\right)\right) \\
& D_{i n t}=\exp \sum_{i}^{n}\left(\frac{L\left(w_{i, t}, w_{i, o}\right)}{\sum_{i}^{n} L\left(w_{i, t}, w_{i, o}\right)} \ln \left(\frac{I_{i, t}}{I_{i, 0}}\right)\right) \\
& L\left(w_{i, t}, w_{i, o}\right)=\frac{w_{i, 0}-w_{i, t}}{\ln \left(\frac{w_{i, 0}}{w_{i, t}}\right)}=\frac{E_{i, 0}}{E_{0}}-\frac{E_{i, t}}{E_{t}} \\
& \left(\frac{E_{i, 0}}{E_{0}}\right) \\
& S_{i}=\frac{Y_{i}}{Y}
\end{aligned}
$$

Where $D_{\text {tot }}$ denotes total energy intensity change in year $\mathrm{t}$, relative to the reference year; $D_{\text {int }}$ denotes changes in aggregate energy intensity due to changes in each subsector energy intensity; $D_{\text {str }}$ denotes changes in aggregate energy intensity due to changes in the structure of the economy; $S_{i}$ denotes the ratio of output of subsector $\mathrm{i}$ to the aggregate output; $w_{i, t}$ is a weight function with factor $i$ in time $t ; w_{i, o}$ is a weight function with factor $i$ in time $O$; $L$ is the logarithmic average of two positive numbers.

This study divides the driving forces affecting energy intensity into two factors: (1) whether an increase in energy consumption in Indonesia is related to the shift to more or less energy-intensive industries (between sector changes/structural effect); and (2) whether it is a result of the improvement or deterioration of energy efficiency (changes within sector energy intensity/intensity effect). Additionally, it will also determine which sectors have the most improved energy consumption, output and energy intensity. By employing energy intensity as an indicator of energy efficiency, this study will investigate whether there was an improvement in energy efficiency in Indonesia's manufacturing sector during the period 1980 to 2015.

\section{Description of data sources}

The primary database used in this study is the Medium and Large Manufacturing Firms Annual Survey of Indonesia, which is collected from the ISB from 1980 until 2015. The number of firms in the survey differs depending on the period of the survey, from the smallest number of firms at around 7471 manufacturers in the 1970 s to the largest number of firms at around 29,568 manufacturers in the 2000s. The ISB organized this survey to collect data comprising basic details of every manufacturer, such as total assets, total income, total expenditures, details in the productions process including total workers, labour expenses, total energy consumption, electricity use, material, value-added, the value of gross output, and details of establishments including the first year of production, industry classifications, locations, ownerships details (that is government, domestic or foreign). The summary report from this survey is published annually, where electronic data are provided with the authorization from ISB officials.

The manufacturing sector featured in this study follows the International Standard Industrial Classification (ISIC) codes with five-digit industrial codes for various economic activities, whereas the ISB modified the firm-level data considering the real situation of Indonesian manufacturing. Throughout the study period, the ISB made several changes in the manufacturing classification to adjust to the increasing number of manufacturers, while also accommodating the ISIC classification changes.

The ISB has conducted surveys of manufacturing annually since 1975 . The most current data are available to 2015. From 1975 to 2015, there have been several reclassifications of industrial data, where adjustments are required to provide a reliable and consistent classification code. The ISB classification changes that occurred during the study period are as follows:

- For period 1980 to 1997 , the data consisted of 30 subsectors of three-digit industry codes starting with 311 until 390 to the base class 24 sectors in twodigit industry codes from 31 to 39 (ISIC Rev. 2 classification).

- For period 1998 to 2010, the data consisted of 66 subsectors of three-digit industry codes starting with 151 until 372 to the base class 23 sectors in twodigit industry codes from 15 to 37 (ISIC Rev. 3 classification).

- For period 2011 to 2015 , the data consisted of 71 subsectors of three-digit industry codes starting with 101 until 332 to the base class 24 sectors in two- 
digit industry codes from 10 to 33 (ISIC Rev. 4 classification).

- Industries refer to three-digit categories. In this study, the data were disaggregated into the two- and three-digit level.

For reasons of compatibility and consistency, this study follows the ISIC Revision 2 (code of 1990) for the data analysis by employing the special map provided by the ISB. As the changes in the ISIC code and reclassifications occurred in the dataset during the study period, this study only uses the dataset for 1980, 1990, 1997, 2000, 2010 and 2015. These different periods were chosen to capture the effects before and after the financial crisis on the changes in aggregate energy intensity in the manufacturing sector.

As mentioned earlier, this study utilized a long data history analysis, therefore for compatibility and consistency reasons, this study follows the ISIC Revision 2 for the data analysis. The ISIC-2 Indonesia's economic activities used in this study is shown in Table 1. The classification of ISIC revision 2 is as follows:

The manufacturing sector in this study is limited to the medium and large the scale manufacturing sector, which accounted for nearly $90 \%$ of aggregate manufacturing value-added. This study is limited to the manufacturing sector as this sector has comprehensive and detailed data (up to the subsector level disaggregation)

Table 1 ISIC-2 Indonesia's economic activities classification

\begin{tabular}{|c|c|c|c|}
\hline ISIC & Sectors & ISIC & Sub-sectors \\
\hline \multirow[t]{4}{*}{31} & \multirow[t]{4}{*}{ Food, Beverages and Tobacco } & 311 & Basic Food \\
\hline & & 312 & Other Food \\
\hline & & 313 & Beverage \\
\hline & & 314 & Tobacco \\
\hline \multirow[t]{4}{*}{32} & \multirow[t]{4}{*}{ Textile, Wearing Apparel and Leather } & 321 & Textiles \\
\hline & & 322 & Wearing apparel \\
\hline & & 323 & leather and leather products \\
\hline & & 324 & Footwear \\
\hline \multirow[t]{2}{*}{33} & \multirow[t]{2}{*}{ Wood and Wood Products } & 331 & Wood and wood and cork products \\
\hline & & 332 & Furniture and fixtures \\
\hline \multirow[t]{2}{*}{34} & \multirow[t]{2}{*}{ Paper and Paper Products } & 341 & Paper and paper products \\
\hline & & 342 & Printing and publishing \\
\hline \multirow[t]{6}{*}{35} & \multirow{6}{*}{$\begin{array}{l}\text { Chemicals, Petroleum, Coal, Rubber } \\
\text { and Plastic Products }\end{array}$} & 351 & Industrial chemicals \\
\hline & & 352 & Other chemical products \\
\hline & & 353 & Petroleum refineries \\
\hline & & 354 & $\begin{array}{l}\text { Miscellaneous products of petroleum } \\
\text { and coal }\end{array}$ \\
\hline & & 355 & Rubber products \\
\hline & & 356 & Plastic products \\
\hline \multirow[t]{5}{*}{36} & \multirow[t]{5}{*}{ Non-Metallic Mineral Products } & 361 & Pottery, china and earthenware \\
\hline & & 362 & Glass and glass products \\
\hline & & 363 & Cement and Lime \\
\hline & & 364 & Clay products \\
\hline & & 369 & Other non-metallic products \\
\hline \multirow[t]{2}{*}{37} & \multirow[t]{2}{*}{ Basic Metal Industries } & 371 & Iron and steel basic industries \\
\hline & & 372 & Non-ferrous metal basic industries \\
\hline \multirow[t]{5}{*}{38} & \multirow{5}{*}{$\begin{array}{l}\text { Fabricated Metal Products, Machinery } \\
\text { and Equipment }\end{array}$} & 381 & Fabricated metal products \\
\hline & & 382 & Machinery \\
\hline & & 383 & Electrical goods and appliances \\
\hline & & 384 & Transport equipment \\
\hline & & 385 & Measuring and controlling goods \\
\hline 39 & Other Manufacturing Industries & 390 & Other Manufacturing Industries \\
\hline
\end{tabular}


that makes it easier to elaborate on the effects of industrial restructuring. Data disaggregation is important in exploring the detail necessary to study the effect of changes in the structure and intensity within subsectors. It is also essential to identify energy-intensive industries among the manufacturing subsector.

\section{Procedures in constructing the dataset}

The ISB manufacturing dataset has been considered by many researchers as one of the best datasets that provides a long period dataset in manufacturing sector statistics [15-17]. Notwithstanding this, the ISB dataset has several drawbacks which need some adjustments to produce a valid and consistent data. Reliable empirical research results can only be obtained from a valid and consistent dataset [18].

Therefore, to construct a consistent dataset, several adjustments have been adopted in this study, as below:

\section{Phase 1: Set definitions for each variable}

As the ISB changed the definition of each variable during the period of observation, this study verifies and compares each variable in the dataset (for the particular year of the study period) to ensure the consistency and validity of the variables. If there is an inconsistency in the variables and definitions, then this study redefines the inconsistent variables to get a consistent definition over the selected period of study.

\section{Phase 2: Correcting for noise in the dataset}

To minimize the noise in the dataset, several steps were taken. First, all of the firms' data which have negative or nil value of energy and value-added are removed. Second, to get consistent data, all of noticeable typo errors and mistakes in the dataset are adjusted. For example, if there are substantial and sharp changes in the value of energy consumption or output, where the overall trend of energy consumption and output in all years is 100\% but nil for other years then adjustments are made by correcting the value of 0 to $100 \%$.

\section{Phase 3: Computing total output/value-added}

The ISIC code provided by the ISB has five digits. The data need to be aggregated into two-digit and three-digit industrial codes to make it comparable across the study period. Output in this study is measured as value-added of Indonesian Rupiah's (in million Rupiah at a constant 1980 price).

\section{Phase 4: Summation of input (energy consumption)}

Energy consumption in this study is the end-use energy consumption by the manufacturing sector. All data are in total fuel consumption, which is the sum of fuel used for manufacturing processes and power generation. The dataset provides different types of fuel used, which include ten types of energy primarily utilized in the manufacturing sector, including gasoline (in L), kerosene (in L), automotive diesel oil (in L), industrial diesel oil (in L), fuel oil (in L), liquid petroleum gas (in kilograms), coal (in $\mathrm{km}$ ), coke (in $\mathrm{km}$ ) and electricity (by $\mathrm{kWh}$ ). These fuel types values were standardised and converted into a standard energy unit: TJ.

\section{Result and discussion}

This section describes the energy-economic characteristics of the manufacturing sector's energy consumption, the manufacturing sector's value added and the results of energy intensity decomposition analysis of the manufacturing sectors.

Energy consumption by type of the manufacturing sector The manufacturing sector has a substantial share of energy use in Indonesia at approximately $40 \%$ of aggregate final energy consumption in 2015, and its consumption has increased by around $4 \%$ per year since the 2000 s. Figure 1 shows the proportion of coal used in manufacturing increased significantly from around $2.5 \%$ in 1980 and to $35 \%$ in 2010 , although there was a decrease after this period to $21 \%$ in 2015 . This decrease in coal consumption was followed by an increase in gas and electricity use during the same period from 29 and $8 \%$ in 2010 to 36 and $12 \%$ in 2015, respectively. Oil was the prominent fuel source in the manufacturing since the 1980s, however, its share decreased from $40 \%$ in 1980 to $31 \%$ in 2015.

One potential reason behind the changes in the manufacturing energy mix is Indonesia's limited natural resources that lead to it restructuring its national energy mix policy. By revising the Presidential Regulation No. 5/2006 and adopting Government Regulation No. 79/ 2014 on National Energy Policy and further with Presidential Regulation No. 22/2017 on National Energy Plan [19], Indonesia's government has introduced several changes to its energy policy planning. The new regulation focuses on re-balancing energy mix to focus on indigenous energy supplies, which includes in reducing oil use, reducing the consumption of coal and renewable energy, and optimising the production and the use of gas. This regulation provides the platform to achieve an energy mix transformation by 2025 to include $30 \%$ coal, $25 \%$ natural gas, $23 \%$ renewable resources and $22 \%$ oil.

Energy consumption and value-added share (ISIC-2 digit) The ISB data at the two-digit level (Table 2) shows there are quite significant changes in the energy consumption share across sub-sectors. In 1980, the share of Food, Beverages and Tobacco (31), Textile (32), Non-metal (36) and Basic Metal (37) accounted for a large share of 


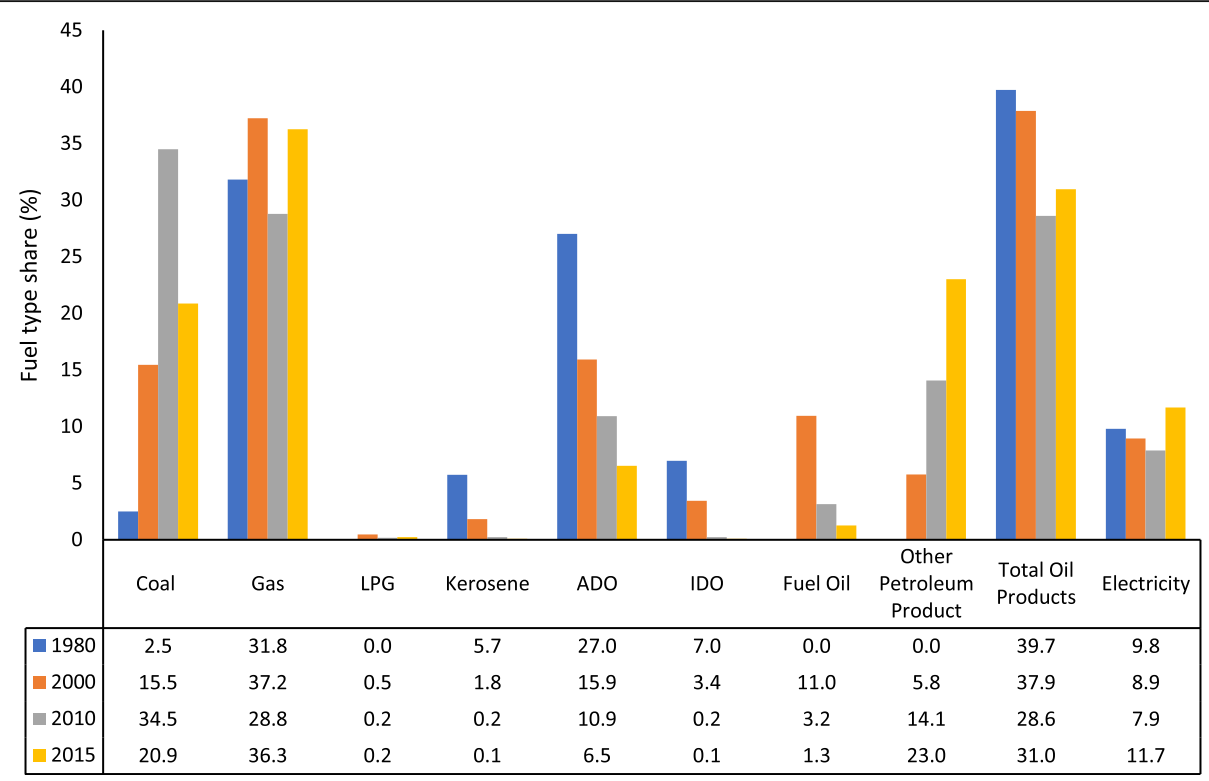

Fig. 1 Total final energy consumption by fuel in manufacturing

energy usage in the manufacturing sector, totalling more than $80 \%$ of total energy share. In 2015, the share of energy consumption in the Textile (32) and Non-metal (36) sectors reduced to around two-third and a half compared to 1980 , respectively. On the other hand, in 2015, the share of energy usage of Food (31), Paper (34), Chemicals (35) and Fabricated metal (38) almost doubled where, according to the National Energy Council [20], the Food, Chemicals and Non-metal sectors are referred to as high energy-consuming industries.

From 1980 to 1990, energy consumption in the manufacturing sector grew, on average, by around $9.9 \%$ a year. Most of the growth in energy use occurred in Food (31), Paper (34), Chemicals (35), Fabricated Metals (38) and
Other Manufacturing Industries (39) where each sector increased its energy consumption by more than $10 \%$. In 1980, Non-metal Mineral Products (including cement and lime) was the largest energy user with total share reaching $43.3 \%$, followed by textile around $16.1 \%$ and Basic Metal approximately $11.2 \%$.

During the financial crisis period of 1997 to 2000, the growth of energy consumption in several manufacturing subsectors decreased quite significantly. During this period, the aggregate energy consumption growth slowed to around $-0.1 \%$, where Non-metal Minerals had the slowest growth compared to other sectors at around $-4.5 \%$. However, after the financial crisis period from 2000 to 2015, energy consumption had moderate growth

Table 2 Share of energy consumption 1980-2015 (ISIC 2-digit)

\begin{tabular}{|c|c|c|c|c|c|c|c|c|c|c|c|c|}
\hline \multirow[t]{2}{*}{ Sectors } & \multirow[t]{2}{*}{ ISIC } & \multicolumn{5}{|c|}{ Annual Growth Rate in Energy Consumption (\%) } & \multicolumn{6}{|c|}{ Share of Total (\%) } \\
\hline & & 80-90 & $90-97$ & 97-00 & 00-10 & $10-15$ & 80-90 & 90-97 & $97-00$ & 00-10 & $10-15$ & 15 \\
\hline Food, Beverages and Tobacco & 31 & 12.8 & 7.6 & 1.3 & 3.4 & 4.4 & 10.3 & 13.4 & 16.0 & 16.7 & 17.0 & 17.7 \\
\hline Textile, Wearing Apparel and Leather & 32 & 7.6 & 3.2 & 2.1 & 2.4 & 3.6 & 16.1 & 13.1 & 11.7 & 12.5 & 11.5 & 11.6 \\
\hline Wood and Wood Products & 33 & 8.7 & 7.5 & 1.1 & 2.3 & 1.2 & 2.5 & 2.2 & 2.7 & 2.8 & 2.5 & 2.3 \\
\hline Paper and Paper Products & 34 & 14.3 & 8.7 & 2.3 & 4.7 & 4.3 & 3.4 & 5.1 & 6.6 & 7.1 & 8.1 & 8.5 \\
\hline $\begin{array}{l}\text { Chemicals, Petroleum, Coal, Rubber } \\
\text { and Plastic Products }\end{array}$ & 35 & 10.5 & 7.6 & 3.2 & 6.8 & 6.9 & 9.0 & 9.6 & 11.4 & 12.6 & 17.7 & 20.8 \\
\hline Non-Metallic Mineral Products & 36 & 9.3 & 2.5 & -4.5 & 0.8 & 0.2 & 43.3 & 41.3 & 35.0 & 30.6 & 24.1 & 20.6 \\
\hline Basic Metal Industries & 37 & 6.8 & 4.6 & 2.5 & 3.5 & 1.3 & 11.2 & 9.7 & 9.5 & 10.2 & 10.5 & 9.5 \\
\hline $\begin{array}{l}\text { Fabricated Metal Products, Machinery } \\
\text { and Equipment }\end{array}$ & 38 & 12.9 & 8.5 & 1.8 & 4.5 & 4.8 & 4.1 & 5.4 & 6.9 & 7.3 & 8.2 & 8.8 \\
\hline Other Manufacturing Industries & 39 & 15.1 & 15.7 & 4.1 & 2.3 & 4.6 & 0.1 & 0.2 & 0.3 & 0.3 & 0.3 & 0.3 \\
\hline AGGREGATE & & 9.9 & 4.9 & -0.1 & 3.2 & 3.5 & & & & & & \\
\hline
\end{tabular}


in most sectors, where the Chemicals (35) experienced the highest growth. Energy consumption in the Chemical sector increase by around 6 to $7 \%$ annually from 2000 to 2015 and its share in aggregate energy consumption was the highest in 2015 at around 20.8\%, followed by Non-Metal (36) and Food (31) at approximately 20.6 and $17.7 \%$, respectively.

The four largest shares of value-added in the manufacturing sector came from Food (31), Textile (32), Chemicals (35) and Fabricated Metal (38). These sectors accounted for more than $75 \%$ of the aggregate valueadded in the manufacturing sector from the 1980s until 2015 (see Table 3). The food industry is one of the most prominent contributors to aggregate value-added in the manufacturing sector. This is potentially due to the government's policy aiming for this sector to achieve selfsufficiency. Fulfilling a sufficient food supply is an essential factor for economic development, hence the government's action in prioritizing the food industry by enacting certain protecting government regulation. Developing resourcebased industries like food and beverages is a significant target for Indonesia, like many other developing countries in Asia [21].

After the Food sector, the second-largest value-added share in 2015 came from the Fabricated Metal sector. The value-added share of this sector increased quite significantly from $17.7 \%$ in 1980 to $23.3 \%$ in 2015. As with the Food sector, one explanation for the high contribution of Fabricated Metal (38) to the aggregate valueadded industry is because the government targeted this sector as one to be prioritized to become self-sufficient. Additionally, the third-highest value-added contributor was the Chemicals industry (35) which accounted for around $19.3 \%$ of aggregate share in 2015 . The significant share of this sector was also a result of the government boosting the domestic value-added for oil, gas and chemical products and reducing import dependence on petrochemical products.

From 1980 to 2015, the value-added contribution of Food (31), Textile (32), Wood (33) and Non-Metal (36) decreased, which were followed by the increasing share of new emerging industries like Paper (34), Chemicals (35) and Fabricated Metal (38). The share of value-added for the textile sector (32) decreased from $13.5 \%$ in 1980 to $10.8 \%$ in 2015 . In 1980, Textile (32) value-added share contributed quite significantly to the manufacturing industry, as the government at this period prioritized this sector to become self-sufficient. Like many other developing countries, Indonesia has employed many policies to enhance industrialisation which utilize labour-intensive and modest technology like garments and textile. The output share of the textile industry increased from 1980 to 1990 from 13.5 to $16.1 \%$, due to the growing export at the beginning of the 1980s and the increasing demand of Indonesia's domestic market [22]. Moreover, Pangestu and Sato [23] listed several driving forces for the increased export opportunities, including the comparatively low labour cost, undervalued real exchange rate, underutilized export quotas and various government incentives, for example, interest rate subsidies for credit exports and export subsidies. However, after it peaked at around 18\% in 2000, the textile output share declined to around $11 \%$ in 2015. Dhanani [24] and Patunru and Rahardja [25] observed several reasons behind this declining share, including the strong competition amongst low-cost Asian textile producers, including India, China and Bangladesh, uncertainty in Indonesia's trade regulation after the Asian financial crisis, and Indonesia's decreasing competitiveness as a result of changes in the minimum wage policy.

During the financial crisis period of 1997 to 2000, the aggregate value-added slowed down quite significantly to about $-4.1 \%$ annually (Table 3), where Fabricated Metal

Table 3 Share of value-added 1980-2015 (ISIC 2 digit)

\begin{tabular}{|c|c|c|c|c|c|c|c|c|c|c|c|c|}
\hline \multirow[t]{2}{*}{ Sectors } & \multirow[t]{2}{*}{ ISIC } & \multicolumn{5}{|c|}{ Annual Growth Rate in value-added (\%) } & \multicolumn{6}{|c|}{ Share of Total (\%) } \\
\hline & & $80-90$ & $90-97$ & $97-00$ & $00-10$ & $10-15$ & $80-90$ & $90-97$ & $97-00$ & $00-10$ & $10-15$ & $80-90$ \\
\hline Food, Beverages and Tobacco & 31 & 13.4 & 6.9 & 3.5 & 4.4 & 9.4 & 31.4 & 25.9 & 19.6 & 24.7 & 24.2 & 28.1 \\
\hline Textile, Wearing Apparel and Leather & 32 & 17.6 & 10.9 & 0.01 & 1.1 & 2.8 & 13.5 & 16.1 & 15.8 & 17.9 & 12.7 & 10.8 \\
\hline Wood and Wood Products & 33 & 20.9 & 5.7 & -12.1 & 0.2 & 1.1 & 7.5 & 11.8 & 8.3 & 6.4 & 4.1 & 3.2 \\
\hline Paper and Paper Products & 34 & 22.1 & 15.0 & 0.45 & 3.6 & 1.2 & 2.8 & 4.8 & 6.0 & 6.9 & 6.3 & 4.9 \\
\hline $\begin{array}{l}\text { Chemicals, Petroleum, Coal, Rubber } \\
\text { and Plastic Products }\end{array}$ & 35 & 13.6 & 11.9 & 0.3 & 5.7 & 6.4 & 17.1 & 14.4 & 15.0 & 17.2 & 19.0 & 19.3 \\
\hline Non-Metallic Mineral Products & 36 & 10.3 & 14.8 & -8.1 & 4.2 & 4.7 & 6.3 & 3.9 & 4.9 & 4.3 & 4.1 & 3.9 \\
\hline Basic Metal Industries & 37 & 7.8 & 3.7 & -6.2 & 5.3 & 7.1 & 3.3 & 9.0 & 5.5 & 5.1 & 5.5 & 5.7 \\
\hline $\begin{array}{l}\text { Fabricated Metal Products, Machinery } \\
\text { and Equipment }\end{array}$ & 38 & 12.6 & 20.5 & -14.8 & 8.1 & 6.3 & 17.7 & 13.6 & 23.8 & 16.7 & 23.2 & 23.3 \\
\hline Other Manufacturing Industries & 39 & 17.2 & 25.4 & -10.9 & 4.5 & 3.4 & 0.4 & 0.5 & 1.1 & 0.9 & 0.9 & 0.8 \\
\hline AGGREGATE & & 15.6 & 11.2 & -4.1 & 4.6 & 6.2 & & & & & & \\
\hline
\end{tabular}


(38) and Wood (33) experienced the largest slowest growth to approximately -15 and $-12 \%$, respectively. However, after the crisis period of 2000 to 2015, the aggregate value-added rose by around 4 to $6 \%$ per year on average, where the Fabricated Metal (38) recorded the strongest growth over the period for around 6 to $8 \%$ annually. Based on the Indonesia Investment Coordinating Board [26] and IEA [2] figures, the increase in the Fabricated metal sector was mostly IEA [2] figures, the increase in the Fabricated metal sector was mostly driven by changes in value-added showed the structural changes of Indonesia's manufacturing sector, whereby from 1980 to 2015, Indonesia's manufacturing sector transformed from labour-intensive to heavy capitalintensive manufacturers (14).

Aggregate energy intensity in the manufacturing sector has improved (decreased) in all key industry subsectors, even though the trends are not similar (see Table 4). Over the $35 \mathrm{yr}$ of 1980 to 2015, the aggregate energy intensity in Indonesia's manufacturing sector decreased by around $65.3 \%$ compared to its base level in 1980. The highest energy intensity reduction occurred in the Nonmetal Mineral industry for around $73.2 \%$, from approximately 0.363 in 1980 to around $0.097 \mathrm{TJ} /$ million Rupiah in 2015.

From 1980 to 1997, the aggregate energy intensity of the manufacturing sector decreased from 0.053 to 0.021 $\mathrm{TJ} /$ million Rupiah. The declining trend in this period was mainly driven by the declining energy intensity in Textile (32), Paper and paper products (34) and Nonmetal (36) sectors. After the financial crisis, in 2000, the aggregate energy intensity increased again to $0.024 \mathrm{TJ} /$ million Rupiah. The energy intensity in most sectors increased quite significantly, including Non-metal (36) and Fabricated Metals (38). However, after the period of financial crisis from 2000 to 2015, the aggregate energy intensity in the manufacturing sector had substantially improved (decreased), where, in 2015, the aggregate energy intensity reached approximately $0.018 \mathrm{TJ} /$ million Rupiah.

\section{Result of decomposition analysis on energy intensity (ISIC-2 digit)}

The decomposition results (see Fig. 2) show that the main driving force reducing the aggregate energy intensity in the manufacturing sector is the intensity effect, while the structure effect only plays a small role in the changes of the aggregate energy intensity in Indonesia's manufacturing sector from 1980 to 2015.

From 1980 to 1990 and 1990 to 1997, the aggregate energy intensity in the manufacturing sector decreased by 40 and 34\%, respectively. Most of the decrease in energy intensity in these periods were attributable to changes within industry energy intensity/intensity effect for around 35 and $36 \%$, respectively. The intensity effect had the highest effect that caused the aggregate energy intensity in the manufacturing sector to decline (see Fig. 2). Additionally, from 1980 to 1990 the role of $\mathrm{D}_{\text {str }}$ contributed to decreasing the aggregate energy intensity by $8 \%$, but from 1990 to 1997, the structural effect increased the aggregate energy intensity by $4 \%$ compared to the base period in 1990.

Throughout the financial crisis period from 1997 to 2000 , the aggregate energy intensity increased to $13 \%$ compared to the base year of 1997 . This increase occurred due to significant changes within industry energy intensity/intensity effect that increased the aggregate energy intensity by $13 \%$. During this period, energy consumption was found to not change much, while the total value-added fell significantly. During this period the role

Table 4 Energy intensity of manufacturing sector (ISIC 2 Digit)

\begin{tabular}{|c|c|c|c|c|c|c|c|c|}
\hline \multirow[t]{2}{*}{ Sectors } & \multirow[t]{2}{*}{ ISIC } & \multicolumn{6}{|c|}{ Energy Intensity (TJ/Million Rp 1980) } & \multirow{2}{*}{$\begin{array}{l}\text { Energy Intensity } \\
\text { Changes (\%) } \\
\text { 1980-2015 }\end{array}$} \\
\hline & & 1980 & 1990 & 1997 & 2000 & 2010 & 2015 & \\
\hline Food, Beverages and Tobacco & 31 & 0.017 & 0.016 & 0.017 & 0.016 & 0.015 & 0.012 & -32.9 \\
\hline Textile, Wearing Apparel and Leather & 32 & 0.063 & 0.026 & 0.016 & 0.017 & 0.019 & 0.020 & -68.8 \\
\hline Wood and Wood Products & 33 & 0.017 & 0.006 & 0.007 & 0.010 & 0.013 & 0.013 & -27.0 \\
\hline Paper and Paper Products & 34 & 0.065 & 0.034 & 0.023 & 0.024 & 0.027 & 0.031 & -52.1 \\
\hline $\begin{array}{l}\text { Chemicals, Petroleum, Coal, Rubber } \\
\text { and Plastic Products }\end{array}$ & 35 & 0.028 & 0.021 & 0.016 & 0.017 & 0.019 & 0.020 & -28.6 \\
\hline Non-Metallic Mineral Products & 36 & 0.363 & 0.332 & 0.151 & 0.169 & 0.121 & 0.097 & -73.2 \\
\hline Basic Metal Industries & 37 & 0.038 & 0.034 & 0.036 & 0.048 & 0.040 & 0.030 & -20.0 \\
\hline $\begin{array}{l}\text { Fabricated Metal Products, Machinery } \\
\text { and Equipment }\end{array}$ & 38 & 0.012 & 0.013 & 0.006 & 0.010 & 0.007 & 0.007 & -44.1 \\
\hline Other Manufacturing Industries & 39 & 0.012 & 0.010 & 0.006 & 0.009 & 0.008 & 0.008 & -35.2 \\
\hline AGGREGATE & & 0.053 & 0.032 & 0.021 & 0.024 & 0.021 & 0.018 & -65.3 \\
\hline
\end{tabular}




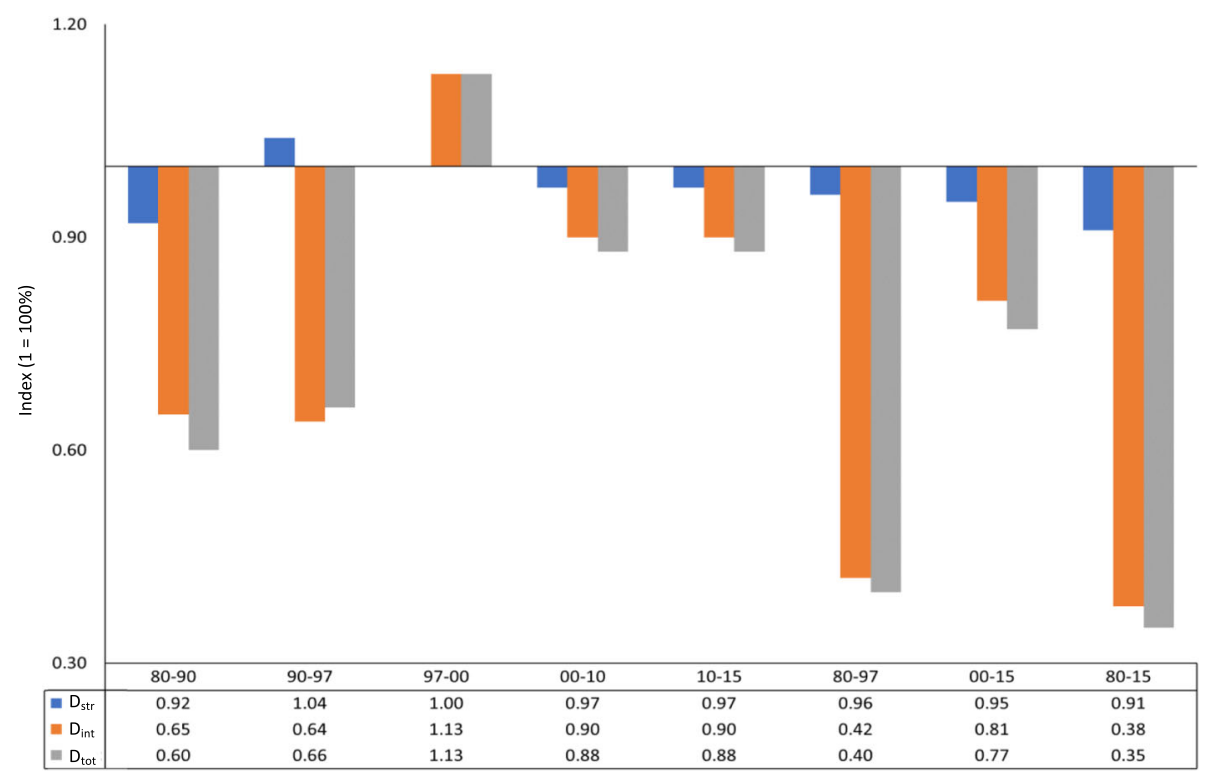

Fig. 2 Decomposition of energy intensity in manufacturing sector (9 sectors) in the period of 1980 to 2015

of the structural effect was found to be negligible to the overall changes in the aggregate energy intensity. The increase of aggregate energy intensity in this period indicated the energy intensity became less efficient, which is a result of the decrease in overall value-added in the manufacturing sector.

Nevertheless, after the peak of energy intensity in 2000 , the aggregate energy intensity in Indonesia from 2000 to 2010 and 2010 to 2015 gradually declined. During both of these periods, the aggregate energy intensity in Indonesia decreased by around $12 \%$ compared to the base year of 2000 and 2010, respectively. Indeed, the changes within industry energy intensity were found quite substantial to decrease the aggregate energy intensity in these periods by around $10 \%$. On the other hand, the role of the structural effect was found to be negligible with only $3 \%$ decrease compared to the intensity effect. Overall, aggregate energy intensity during 1980 to 2015 declined. During the study, the changes within industry energy intensity played the greatest role, reducing the aggregate energy intensity by around $62 \%$, while the structural effect only decreased by $9 \%$ compared to its base year in 1980 .

From the above decomposition results, two periods are notable. First, this period is tagged as "the period before and after the financial crisis." Both trends of intensity effect and structural effect during the period of before the crisis (1980 to 1997) and after the crisis (2000 to 2015) showed a decreasing trend in aggregate energy intensity in the manufacturing sector. The decreasing changes within industry energy intensity/intensity effect potentially could be related to the advancement of energy-efficient technology in the key manufacturing industries, for instance, technology upgrades in the high energy intensity sector, such as Non-Metal and Textile sectors, where these two sectors showed a substantial improvement (decrease) in energy intensity. Indeed, the decreasing trend of structural effect during both periods of 1980 to 1997 and 2000 to 2010 also affirmed the decreasing trend of aggregate energy intensity in the manufacturing sector, where the decreasing of structural effect showed a shift to less energy-intensive industry.

Second, this period is called as "the period during the financial crisis." During the crisis period of 1997 to 2000, changes within industry increased the aggregate energy intensity in the manufacturing sector. The increasing of energy intensity in this period is most likely due to falling of overall output in the key manufacturing sector. Tables 2 and 3 show that the annual growth of value-added is slower than the annual growth of energy consumption, which results in deterioration in aggregate energy intensity in the manufacturing sector.

A rapid industrialisation process took place in the manufacturing sector which had experienced quite significant structural changes throughout the study. Manufacturing sectors output grew significantly from 1980 to 1997. However, during the economic crisis from 1997 to 2000, the growth rate of all subsectors slowed down. Hill [27] concluded that the key factor of industrial transformation in Indonesia between the period of the 1970s to 1990s was due to its fast diversification. Additionally, Rodrik [28] also claims that the major dimension to 
economic development is product diversification. Ultimately, the structural shifts in Indonesia's manufacturing sector indicate the change from light industries with labour intensive to heavy industries with more capital and technology-intensive [29].

The historical trend of decomposition results reveals that the intensity effect reduction in the manufacturing sector had changed through different periods. This trend of decomposition demonstrates the consequences of the financial crisis on the changes of aggregate energy intensity which could limit the growth of certain manufacturing sectors from structural and intensity changes.

\section{Conclusions}

The main objective of this study was to investigate the energy efficiency performances in the manufacturing sector by examining the past changes in energy consumption and energy intensity in Indonesia's manufacturing sector from 1980 to 2015.

The rapid industrialisation process in Indonesia is accompanied with a significant structural shift across subsectors within the manufacturing industry. Indonesia's manufacturing sector has increased its economic output substantially between 1980 and 2015. During this period, the proportional contribution to overall GDP of food (31), textile (32), wood (33) and Non- metal (36) industries decreased, while Paper (34), Chemicals (35), Basic metal (37) and fabricated metal (38) industries increased their share to total output. Food and Fabricated metal sectors are the two largest contributor sectors to overall value-added over the study period, whereas both sectors also have the smallest energy intensity compared to other manufacturing sectors. During the study period, the value-added contribution from the food manufacturing sector has slightly decreased, whilst the value-added contribution from fabricated metal industries increased significantly.

The decomposition results show that the main driving force to reduce the aggregate energy intensity in manufacture sector is the intensity effect within industry changes, while the structure effect only plays a small role to reduce the overall energy intensity in Indonesia's manufacturing sector during the study period of 1980 to 2015. Between 1980 to 1997, the intensity effect and structural effect decreased the aggregate energy intensity significantly, which suggested efficiency improvements in energy use, especially in the Textile, Non-metal and Chemicals sectors, where a large fall in energy intensity effect occurred. Signals of the structural effect improvements (a decrease) also occurred in most of these industries, except for the Chemicals subsector which experienced an increase in the structural effect which indicated a shift to more energy-intensive industry.
However, following Indonesia's economic crisis from 1997 to 2000, which dropped the aggregate economic growth and exchange rate, the contribution of these effects changed compared to the previous period. The intensity effects in most subsectors increased and dominated the changes in aggregate energy intensity. The greatest increase in the intensity effect occurred in the Basic Metal industry. However, during this period, the Food industry experienced a decrease in its intensity effect. The increase of changes within industry energy intensity led to an increase in aggregate energy intensity, while the role of structural effect was found smaller compared to within industry changes.

After the crisis period of 2000 to 2015, changes within industry energy intensity again reduced the aggregate energy intensity, and the structural effect also increased the magnitude of the reduction of aggregate energy intensity. For instance, the intensity effect in the Food industries, Nonmetal and Basic Metal experienced a substantial decrease to aggregate subsectors energy intensity, although within industry changes in the Textile and Chemicals industries had an increasing effect. Indeed, the role of structural effect also indicated a decrease in most of these sectors, except for the Food sector, which showed an increase.

Indonesia's economy had gradually improved after the crisis period from 2000 to 2015, which also ameliorated the aggregate energy intensity in the manufacturing sector. This improvement in the manufacturing's energy intensity potentially is a result of the enforcement of energy efficiency policy in Indonesia, specifically the government regulation No. 70 of 2009 that regulates all of the energy users greater than $6 \mathrm{kt}$ of oil equivalent [30]. Additionally, the Indonesian government had also reformed its energy subsidy which significantly increased the energy prices specifically for the manufacturing sector. IEA [2] highlights the tendency of higher energy prices to foster industry efficiency. Indeed, all of these policy measures had encouraged manufacturers to enhance their competitiveness and minimize their energy intensity, including investing in new and efficient technologies to enhance its energy productivity.

The analysis also revealed that the greatest energy intensity sector is the Non-metal sector (particularly the cement and lime sector). This sector consumed more energy per value-added and involves a large share of Indonesia's manufacturing energy use compared to other sectors. Furthermore, the decomposition results reveal that the intensity effect reduction in the manufacturing sector changes through different periods. The trend helps to understand the consequences of economic incidents which could limit the growth of some industries from structural change and energy use. However, besides these driving forces, some other factors might also have influenced the overall trends and it is hard to offer a single explanation. 


\section{Acknowledgements}

The author would like to thank Professor Peter Sheehan and Dr. Steven Parker, Victoria University, Melbourne, Australia for their valuable insights and contributions to the study. The author also wishes to express gratitude to the Fiscal Policy Agency, Ministry of Finance of the Republic of Indonesia for providing facilities and to the Australian Awards Scholarship for providing funding that has made this research endeavour possible.

\section{Author's contributions}

The author carried out research work and wrote the article. The author read and approved the final manuscript.

\section{Funding}

The author's research is funded and supported by the Australian Awards Scholarship and the Ministry of Finance of the Republic of Indonesia.

\section{Availability of data and materials}

All data generated or analysed during this study are available from the corresponding author on reasonable request.

\section{Competing interests}

The author declares that he has no competing interests.

Received: 15 December 2019 Accepted: 5 May 2020

Published online: 15 June 2020

\section{References}

1. ADB. Fossil fuel subsidies in Indonesia: trends, impacts, and reforms. Manila: Asian Development Bank; 2015

2. IEA. Energy Efficiency 2017. Paris: International Energy Agency; 2017.

3. ISB. Series of Indices of Manufacturing Industry 2017-2019. Jakarta: Indonesian Statistical Bureau; 2019. [in Indonesian].

4. Azam M, Khan AQ, Zaman K, Ahmad M. Factors determining energy consumption: evidence from Indonesia, Malaysia and Thailand. Renew Sust Energ Rev. 2015:42:1123-31.

5. Hwang $\mathrm{JH}, \mathrm{YoO} \mathrm{SH}$. Energy consumption, $\mathrm{CO}_{2}$ emissions, and economic growth: evidence from Indonesia. Qual Quant. 2014;48:63-73.

6. Hasan MH, Mahlia TMI, Nur H. A review on energy scenario and sustainable energy in Indonesia. Renew Sust Energ Rev. 2012;16:2316-28.

7. Hartono D, Irawan T, Achsani NA. An analysis of energy intensity in Indonesian manufacturing. Int Res J Financ Econ. 2011;62:77-84.

8. Vivadinar $Y$, Purwanto $\mathrm{WW}$, Saputra AH. What are the key drivers of energy intensity in Indonesia manufacturing sectors? In: 2012 International Congress on Informatics, Environment, Energy and Applications. Singapore; 2012.

9. Sitompul RF. Energy-related $\mathrm{CO}_{2}$ emissions in the Indonesian manufacturing sector [Ph.D. dissertation]. Sydney: Univ of New South Wales; 2006.

10. Sun JW. Changes in energy consumption and energy intensity: a complete decomposition model. Energ Econ. 1998:20:85-100.

11. Ramstetter $E D$, Narjoko D. Ownership and energy efficiency in Indonesian manufacturing. B Indones Econ Stud. 2014;50:255-76.

12. Setyawan D. Economy-wide energy efficiency using a comprehensive decomposition method. Glob J Environ Sci Manag. 2020;6:385-402.

13. Ang BW. Decomposition analysis for policymaking in energy: which is the preferred method? Energ Policy. 2004;32:1131-9.

14. Ang BW. The LMDI approach to decomposition analysis: a practical guide. Energ Policy. 2005;33:867-71.

15. Suatmi BD. Liberalization reform and productivity growth in Indonesia: firm level evidence [Ph.D. Dissertation]. Perth: Curtin Univ; 2016.

16. Narjoko D, Hill H. Winners and losers during a deep economic crisis: firm-level evidence from Indonesian manufacturing. Asian Econ J. 2007:21:343-68

17. Amiti M, Konings J. Trade liberalization, intermediate inputs, and productivity: evidence from Indonesia. Am Econ Rev. 2007;97:1611-38

18. Leung L. Validity, reliability, and generalizability in qualitative research J Fam Med Prim Care. 2015;4:324-7.

19. GOI. Government Regulation of the Republic of Indonesia No. 22/2017 on National Energy Plan. Jakarta: Government of Indonesia; 2017. https://sipuu. setkab.go.id/PUUdoc/175146/Perpres\%2022\%20Tahun\%202017.pdf [in Indonesian].
20. NEC. Indonesia Energy Outlook 2016. Jakarta: National Energy Council; 2016. https://www.esdm.go.id/assets/media/content/outlook_energi_indonesia_2 016_opt.pdf [in Indonesian].

21. Felipe J, Estrada G. Benchmarking developing Asia's manufacturing sector. Manila: Asian Development Bank; 2007.

22. Ikhsan M. Total factor productivity in Indonesian manufacturing: a stochastic frontier approach. Glob Econ Rev. 2007;36:321-42.

23. Pangestu ME, Sato Y, editors. Waves of change in Indonesia's manufacturing industry. Tokyo: Institute of Developing Economies; 1997.

24. Dhanani S. Indonesia: strategy for manufacturing competitiveness. Vienna: United Nations Industrial Development Organization; 2000.

25. Patunru AA, Rahardja S. Trade protectionism in Indonesia: bad times and bad policy. Sydney: Lowly Institute for International Policy; 2015.

26. IICB. Statistic of foreign direct investment realization based on capital investment activity report by sector, Q2 2017. Jakarta: Indonesia Investment Coordinating Board; 2017.

27. Hill H. Indonesia's industrial transformation part I. B Indones Econ Stud. 1990;26:79-120

28. Rodrik D. Industrial development: Some stylized facts and policy directions. Industrial development for the $21^{\text {st }}$ century: sustainable development perspectives. New York: United Nations; 2007. p. 7-28.

29. Widodo W. Agglomeration economies, firm-level efficiency, and productivity growth: empirical evidence from Indonesia. B Indones Econ Stud. 2014:50:291-2.

30. GOI. Government Regulation of the Republic of Indonesia No. 70/2009 on Energy Conservation. Jakarta: Government of Indonesia; 2009.

\section{Publisher's Note}

Springer Nature remains neutral with regard to jurisdictional claims in published maps and institutional affiliations.

Ready to submit your research? Choose BMC and benefit from:

- fast, convenient online submission

- thorough peer review by experienced researchers in your field

- rapid publication on acceptance

- support for research data, including large and complex data types

- gold Open Access which fosters wider collaboration and increased citations

- maximum visibility for your research: over $100 \mathrm{M}$ website views per year

At BMC, research is always in progress.

Learn more biomedcentral.com/submission 